\title{
Landscape-scale variability of soil health indicators: effects of cultivation on soil organic carbon in the Usambara Mountains of Tanzania
}

\author{
Leigh Winowiecki · Tor-Gunnar Vågen • Boniface Massawe • \\ Nicolas A. Jelinski - Charles Lyamchai - George Sayula • \\ Elizabeth Msoka
}

Received: 12 February 2015/Accepted: 2 November 2015/Published online: 7 November 2015

(C) The Author(s) 2015. This article is published with open access at Springerlink.com

\begin{abstract}
Land-use change continues at an alarming rate in sub-Saharan Africa adversely affecting ecosystem services provided by soil. These impacts are greatly understudied, especially in biodiversity rich mountains in East Africa. The objectives of this study were to: conduct a biophysical baseline of soil and land health; assess the effects of cultivation on soil organic carbon (SOC); and develop a map of SOC at high resolution to enable farm-scale targeting of management interventions. Biophysical field surveys were conducted in a $100 \mathrm{~km}^{2}$ landscape near Lushoto, Tanzania, with composite soil samples collected from 160 sampling plots. Soil erosion prevalence was scored, trees were counted, and current and historic land use was recorded at each plot. The results of the study showed a decline in SOC as a result of cultivation, with cultivated plots $(n=105)$ having
\end{abstract}

\section{Winowiecki $(\bowtie)$}

International Center for Tropical Agriculture (CIAT),

Nairobi, Kenya

e-mail: 1.a.winowiecki@cgiar.org

T.-G. Vågen

World Agroforestry Centre (ICRAF), Nairobi, Kenya

B. Massawe

School of Environment and Natural Resources, Ohio State

University, Columbus, OH, USA

B. Massawe

Department of Soil Science, Sokoine University of

Agriculture, Morogoro, Tanzania mean topsoil OC of $30.6 \mathrm{~g} \mathrm{~kg}^{-1}$, while semi-natural plots $(\mathrm{n}=55)$ had $71 \mathrm{~g} \mathrm{OC} \mathrm{kg}^{-1}$ in topsoil. Cultivated areas were also less variable in SOC than seminatural systems. Prediction models were developed for the mapping of SOC based on RapidEye remote sensing data for January 2014, with good model performance $\left(\mathrm{RMSEP}_{\mathrm{cal}}=8.0 \mathrm{~g} \mathrm{~kg}^{-1} ; \mathrm{RMSEP}_{\mathrm{val}}=\right.$ $10.5 \mathrm{~g} \mathrm{~kg}^{-1}$ ) and a SOC map was generated for the study. Interventions will need to focus on practices that increase SOC in order to enhance productivity and resilience of the farming system, in general. The highresolution maps can be used to spatially target interventions as well as for monitoring of changes in SOC.

Keywords Land-use change - Land health . Cropping diversity

\author{
N. A. Jelinski \\ Department of Soil, Water and Climate, University of \\ Minnesota- Twin Cities, Minneapolis, MN, USA \\ C. Lyamchai - G. Sayula \\ Selian Agriculture Research Institute (SARI), Arusha, \\ Tanzania \\ E. Msoka \\ Lushoto District Council, Lushoto, Tanzania
}




\section{Introduction}

Soil organic carbon (SOC) is an important component of the soil ecosystem and an indicator of soil health. Therefore, maintaining SOC is recognized as an important strategy for building efficiency and resilience of the system (Lal 1987, 2010; Vågen et al. 2012; Victoria et al. 2012; FAO 2013). The United Nations Convention to Combat Desertification (UNCCD) and the United Nations Framework Convention on Climate Change (UNFCCC) both recognize that reduced SOC content can lead to land degradation, and ultimately low land and agricultural productivity. It is estimated that while $70 \%$ of Africa's population lives in rural areas and depends almost solely on agriculture, over half of Africa's land is unsuitable for agriculture (Swift and Shepherd 2007). Yet, the impacts of land-use change on SOC dynamics in sub-Saharan African ecosystems are still understudied, especially across diverse landscapes. Meta-analyses have shown that the conversion of forest/natural vegetation to agriculture leads to an overall loss of SOC (Post and Mann 1990; Schlesinger 1997; Ogle et al. 2005; Vågen et al. 2005; Don et al. 2011), which has resulted in renewed efforts for restoring OC in agricultural soils (Lal et al. 2004; Lal 2007; Tittonell and Giller 2013; Vanlauwe et al. 2014). However, systematic surveys are needed to understand spatial variability of soil health indicators across the landscape, including interactions between inherent soil properties, SOC dynamics and land use, that enable targeted interventions at the plot and landscape-scales.

Agriculture (including livestock keeping) is the mainstay of the Tanzanian economy, involving over $80 \%$ of the population (URT 2001). While the sector's contribution to the GDP of Tanzania has decreased over time (from $46 \%$ in 2001 to $26 \%$ in 2008; URT 2008) ongoing continent-wide initiatives are focused on increasing agriculture's contribution to GDP by $6 \%$ per annum (URT 2011). These renewed efforts to expand growth in the agricultural sector must now also grapple with the confounding factors of climate change, in addition to the negative environmental impacts of past exhaustive farming practices (URT 2012; Kangalawe and Lyimo 2013; Rwehumbiza 2014). The Western Usambara Mountains (WUM) in northeastern Tanzania represent a biodiversity hotspot in East Africa (Critical Ecosystem
Partnership Fund 2005) that is experiencing extreme population pressure and increased poverty coupled with agricultural growth. The landscape has transitioned from predominantly endemic vegetation to a matrix of agricultural fields of varying sizes, management strategies, and crops; timber plantations (e.g. Juniperus procera, Cupressus Lusstanica, Pinus petula and Pinus radiate; Van Olmen 2008; Masunga 2009) and patches of natural rainforest. Over-cultivation, soil erosion and low soil fertility (Lundgren 1980; Tenge et al. 2005, 2007; Ndakidemi and Semoka 2006; Wickama et al. 2014) coupled with decreasing farm size, low crop productivity, and erratic weather patterns (Msita et al. 2010; Lyamchai et al. 2011; Msita 2013; Kimaro et al. 2014) are all major challenges facing smallholder farmers in the region. In order to address the complexity of the challenges facing natural resource management in both the agricultural and livestock sectors, studies and research at local and national scales need to better assess and develop "best-bet" spatially explicit options for sustainable agricultural growth.

Quantifying the effect of land management strategies on dynamic soil properties is complicated by the natural complexity of soil across space (Robertson et al. 1993; Heuvelink and Webster 2001; Lin et al. 2005; Huang et al. 2007) and time. This study aims to build on previous efforts to address soil fertility constraints in African smallholder systems by applying a spatially balanced sampling design that accounts for landscape variability in SOC in order to assess the impacts of cultivation on SOC in the WUM of Tanzania. Specifically, the objectives of this study were to: (1) to conduct a biophysical baseline of multiple soil and land health metrics across the landscape; (2) to assess the effects of cultivation on SOC and (3) to develop a map of SOC at high resolution to enable farm-scale targeting of management interventions.

\section{Methods}

Site description

The Lushoto study site lies within the WUM, with elevations ranging from 850 to $1900 \mathrm{~m}$ and average slopes of about $17^{\circ}$. Average rainfall was $962 \pm$ $266 \mathrm{~mm}$ for the years between 1999 and 2012, with 
high variability between years. Geologically, the WUM are part of the Eastern Arc Mountains, a crystalline geologic range along the eastern edge of Tanzania. The landscape on the plateau of the WUM is grouped into four broad units: high altitude plateau, mid altitude plateau, low altitude plateau and the elongated valley bottoms. In general, the soils of WUM vary strongly from Regosols and Lithic Leptosols on ridge crests and upper slopes, and Cutanic Acrisols and Ferralic Cambisols dominant on the mid and lower slopes (Massawe 2011). Differences in geomorphology and surface water features result in two major types of valley bottom soils across the study site: Mollic Gleyic Fluvisols and Fluvic Gleysols (Massawe 2011). Major crops in the study area include maize, beans, potatoes, cassava, vegetables (such as tomatoes, cabbages, peppers), coffee and temperate fruits (such as avocados and peaches), which are grown for both home consumption and as cash crops (Lyamchai et al. 2011). Despite the high diversity of crop production, food insecurity remains high (Kristjanson et al. 2012).

\section{Soil and land health survey}

We applied the Land Degradation Surveillance Framework (LDSF) (Vågen et al. 2010, 2013b; Vågen and Gumbritch 2012) in order to assess land and soil health in the study area. The LDSF is a spatially stratified hierarchical sampling design aimed at assessing key land and soil health metrics across diverse landscapes (Fig. 1). The Lushoto LDSF site was surveyed in November 2012 as part of the Climate Change, Agriculture, and Food Security (CCAFS) Research Program of the Consultative Group for International Agricultural Research (CGIAR; http:// ccafs.cgiar.org).

Observations were made at both plot-level $\left(1000 \mathrm{~m}^{2}\right)$ and subplot-level $\left(100 \mathrm{~m}^{2}\right)$. At each $1000 \mathrm{~m}^{2}$ plot $(\mathrm{n}=160)$ observations of slope, vegetation structure, topographic position, land management and land-use history were made. While observations of erosion, as well as tree and shrub densities were conducted within each $100-\mathrm{m}^{2}$ subplot. A total of 320 standard soil samples were collected for the site, with samples collected at 0-20 and 20-50 cm, combining the soil samples from each subplot into one sample for topsoil and one for subsoil, respectively.

Soil laboratory analysis

Soil samples were air-dried and ground to pass through a 2-mm sieve. A subset of 30 standard topand sub-soil samples were analyzed for $\mathrm{OC}, \mathrm{pH}$,
Fig. 1 The Land Degradation Surveillance Framework (LDSF) sampling design, showing the layout of a site (upper left), cluster (upper right), and plot and subplot (lower right)

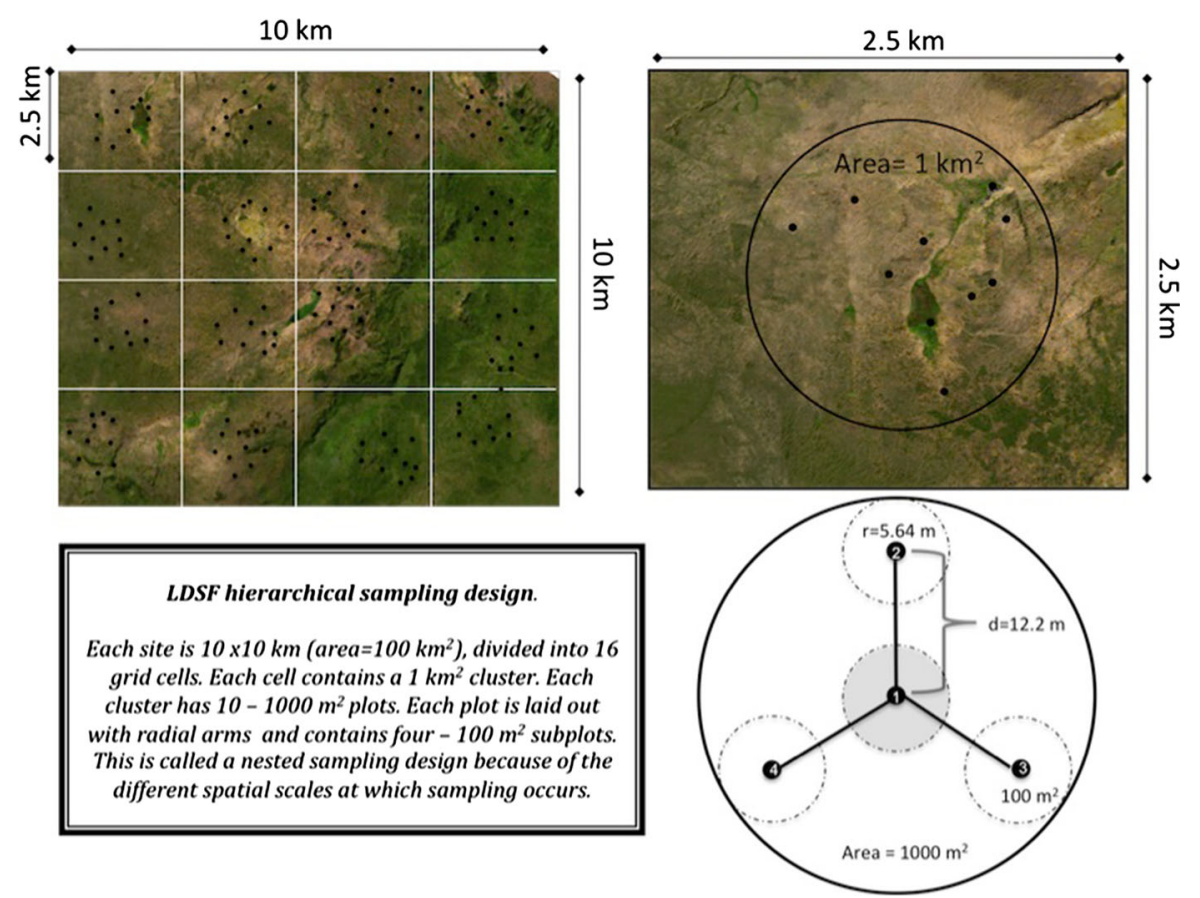


exchangeable bases and texture. $\mathrm{pH}$ was analyzed in a 1:2 $\mathrm{H}_{2} \mathrm{O}$ mixture (20 g of soil: $40 \mathrm{~mL}$ de-ionized water) that was shaken for $30 \mathrm{~min}$ at moderate speed on a horizontal shaker then let stand for $20 \mathrm{~min}$ before reading on a Eutech Cyberscan $1100 \mathrm{pH}$ meter. Exchangeable bases were extracted using a Mehlich3 method (Mehlich 1984; $4 \mathrm{~g}$ of soil in $40 \mathrm{~mL}$ of the Mehlich 3 extracting solution) after being shaken for $5 \mathrm{~min}$ on a reciprocating shaker. The filtrate was analyzed for base cations: potassium (K), calcium (Ca), magnesium $(\mathrm{Mg})$ and sodium $(\mathrm{Na})$ on ICP OES (Model-Thermo iCAP6000 Series) at Crop Nutrition Laboratory Services in Nairobi, Kenya. Total N and OC were measured by dry combustion using an Elemental Analyzer Isotope Ratio Mass Spectrometry (EA-IRMS) from Europa Scientific after removing inorganic $\mathrm{C}$ with $0.1 \mathrm{~N} \mathrm{HCl}$, at the IsoAnalytical Laboratory located in the United Kingdom. Sand content was measured using a Laser Diffraction Particle Size Analyzer (LDPSA) from HORIBA (LA 950) after shaking each soil sample for $4 \mathrm{~min}$ in a $1 \%$ sodium hexametaphosphate (calgon) solution, at the World Agroforestry Centre (ICRAF) Soil-Plant Spectral Diagnostics Laboratory in Nairobi, Kenya.

Soil samples analyzed for MIR absorbance were processed in the following way: a subsample of $\sim 10 \mathrm{~g}$ was further dried at $40{ }^{\circ} \mathrm{C}$ for $24 \mathrm{~h}$. Dried samples were ground using RM 200 Retsch motor grinder to attain a particle size between 20 and $53 \mu \mathrm{m}$. Soil (about 1-2 g) was then loaded into the aluminum sample plate, in triplicate. MIR absorbance was measured on the Tensor 27 HTS-XT from Bruker Optics located at the ICRAF Soil-Plant Spectral Diagnostics Laboratory in Nairobi, Kenya. The MIR spectra were added to the ICRAF pan African MIR spectral library. The measured wavebands ranged from 4000 to $601 \mathrm{~cm}^{-1}$ with a resolution of $4 \mathrm{~cm}^{-1}$. Soil samples that have both MIR spectra and associated wet chemistry data were used to develop the MIR prediction models for the various soil properties (Vågen et al. 2016). Processing of the MIR spectra followed the procedures outlined in Terhoeven-Urselmans et al. (2010), with first derivatives computed using a Savitsky-Golay polynomial smoothing filter implemented in the locpoly function of the KernSmooth R package (Wand 2015) prior to fitting a random forest (RF) prediction model to the samples from the study area. Random forest modeling is an ensemble modeling approach, where many weak learners (decision trees) are combined or bagged to predict an outcome, SOC in this case (Breiman 2001).

The 30 standard top- and sub-soil samples were used to validate (test) the performance of the global RF model.

\section{Statistical analysis}

The effects of land use practices on SOC were assessed by using a linear mixed effects (lme) model with $\ln$ (SOC) as dependent variable, land use as the independent variable and sampling clusters as random effects. The reason for the choice of a mixed-effects modelling approach was the hierarchical nature of the data, and the need for an approach that takes the grouping effects in the data into account. All calculations and statistical analysis were conducted using $\mathrm{R}$ statistics (R Core Team 2015) and KNIME (Berthold et al. 2007).

\section{Mapping of SOC based on RapidEye imagery}

A RF prediction model for the mapping of SOC in the topsoil using RapidEye reflectance data was developed based on laboratory MIR predicted SOC. Specifically, we used RapidEye reflectance data from 14 LDSF sites, covering a wide range in SOC (0.87-160 $\mathrm{g} \mathrm{C} \mathrm{kg}^{-1}$ ) for development of the prediction model. The reason for including additional sites in the model is to develop robust remote sensing based prediction models that can be applied across a wider range of sites, which requires representative input data (e.g., covering a range of soil types, RapidEye spectral conditions and SOC). We tested and applied this model to Lushoto using the following method. RapidEye reflectance was extracted for the Lushoto LDSF plots by taking the median reflectance of each band for the pixels falling within each plot, using a RapidEye image from 11 January 2014, and ingested into a library of RapidEye reflectance data from a total of 14 LDSF sites. The prediction model for SOC was developed using threefold cross-validation without replacement by randomly drawing two-thirds of the data for calibration $(\mathrm{N}=1203)$ and using the remaining one third of the samples $(\mathrm{N}=602)$ for validation in each test run. Model accuracy was assessed by calculating the root-mean-squared error of prediction (RMSEP) for predicted versus measured SOC in both the calibration and validation model runs. 


\section{Results and discussion}

\section{Mid-infrared spectroscopy}

Infrared spectroscopy is a well-established methodology for predicting important soil properties such as SOC, $\mathrm{pH}$, base cations, TN and texture (Shepherd and Walsh 2002; Brown et al. 2006; Reeves III et al. 2006; Vågen et al. 2006; Madari et al. 2006; Terhoevenurselmans et al. 2010). Figure 2 shows measured vs predicted values for each soil property, using the 30 top- and sub-soil samples from Lushoto. Prediction model performance was excellent for all soil properties with $\mathrm{r}^{2}$ values of 0.99 for SOC and TN 0.96 for $\mathrm{pH}$ 0.92 for exchangeable bases and 0.94 for clay. These results are better than those reported by TerhoevenUrselmans et al. (2010) for a globally distributed library of soil laboratory spectra, mostly due to the much larger sample size available for model development in our study and consistent laboratory methods used for all samples. The results presented in the following sections are derived from MIR-predicted soil property values.

\section{Summary of soil characteristics}

Maintenance of soil fertility is an important ecosystem service as it is necessary for overall agricultural productivity. Table 1 shows the ranges of important soil fertility indicators such as SOC, TN, pH, exchangeable bases and sand for the site. The soils of Lushoto have high variability, with $\mathrm{pH}$ ranging from 4.4 to 7.8 and exchangeable bases ranging from 37 to 408 mmol $_{\mathrm{c}} \mathrm{kg}^{-1}$ (Table 1). About $38 \%$ of the topsoil samples were at or below a critical level for exchangeable bases of $80 \mathrm{mmol}_{\mathrm{c}} \mathrm{kg}^{-1}$. It will be important to assess the impact of particular management strategies on each of these soil fertility indicators, as even woodland and forests are impacted by human activities, through charcoal production, firewood collection and grazing. In a soil survey conducted in 2006, the authors reported high variability in soil nutrient status (e.g., $\mathrm{pH}$ and exchangeable bases), and approximately $90 \%$ of the soils in the region reported to be deficient in phosphorus, while $\mathrm{N}$ deficiency was reported in $\sim 73 \%$ of the soils (Ndakidemi and Semoka 2006). They also observed high variation in SOC, but did not analyze the effects of management on SOC.
Effects of cultivation on carbon

There is a strong effect of cultivation on SOC overall in the study area, with cultivation resulting in significantly lower SOC content in both top- and sub-soil ( $p<0.025$; Fig. 3), based on a linear mixed effects models with random effects at cluster and plot levels. Variance is higher between clusters than within clusters, highlighting the importance of landscapelevel sampling approach used in this study. Cultivated plots $(\mathrm{n}=105)$ had mean topsoil SOC of $30.1 \mathrm{~g} \mathrm{~kg}^{-1}$, while non-cultivated plots $(\mathrm{n}=55)$ had $71 \mathrm{~g} \mathrm{SOC} \mathrm{kg}^{-1}$ on average. As shown in Fig. 3, cultivation not only leads to lower SOC but also decreases the variability in SOC in both top- and subsoil.

These results show that current cultivation practices are leading to sharp declines in SOC in Lushoto, and interventions need to focus on practices that increase SOC in order to improve the capacity of the soil ecosystem to provide the supporting and provisioning services, including agricultural productivity and the adaptive capacity of the farming systems in general. While it is not entirely surprising that cultivation decreases SOC, it is surprising that Lushoto soils have lost $\sim 50 \%$ of the carbon compared to semi-natural areas in the study site. Forested soils had high overall carbon (up to $150 \mathrm{~g} \mathrm{~kg}^{-1}$ ), due to high biomass production as well as well aggregated, highly weathered soils that protect the SOC. However, once cleared, processes of land degradation, such as soil erosion, and general mining of the soil through nonreplenishing agricultural practices, lead to an overall decline in SOC. This has important implications for the long-term sustainability of these systems, including the effect on other soil fertility parameters.

Effects of SOC on other soil properties

SOC influences many soil properties such as aggregate stability, water holding capacity, TN, cation exchange capacity (CEC) and $\mathrm{pH}$. In addition, there is often a strong correlation between SOC and TN in soils, which allows one to make inferences about soil TN based on SOC. As shown in Fig. 4, the relationship between OC and TN is almost linear in both cultivated (1) and non-cultivated (0) plots in the Lushoto landscape. As SOC increases, so does TN content. It has been suggested that a threshold value of $0.2 \% \mathrm{~N}$ 
Fig. 2 Measured versus predicted soil properties using MIR spectroscopy for the 30 reference soil samples in Lushoto
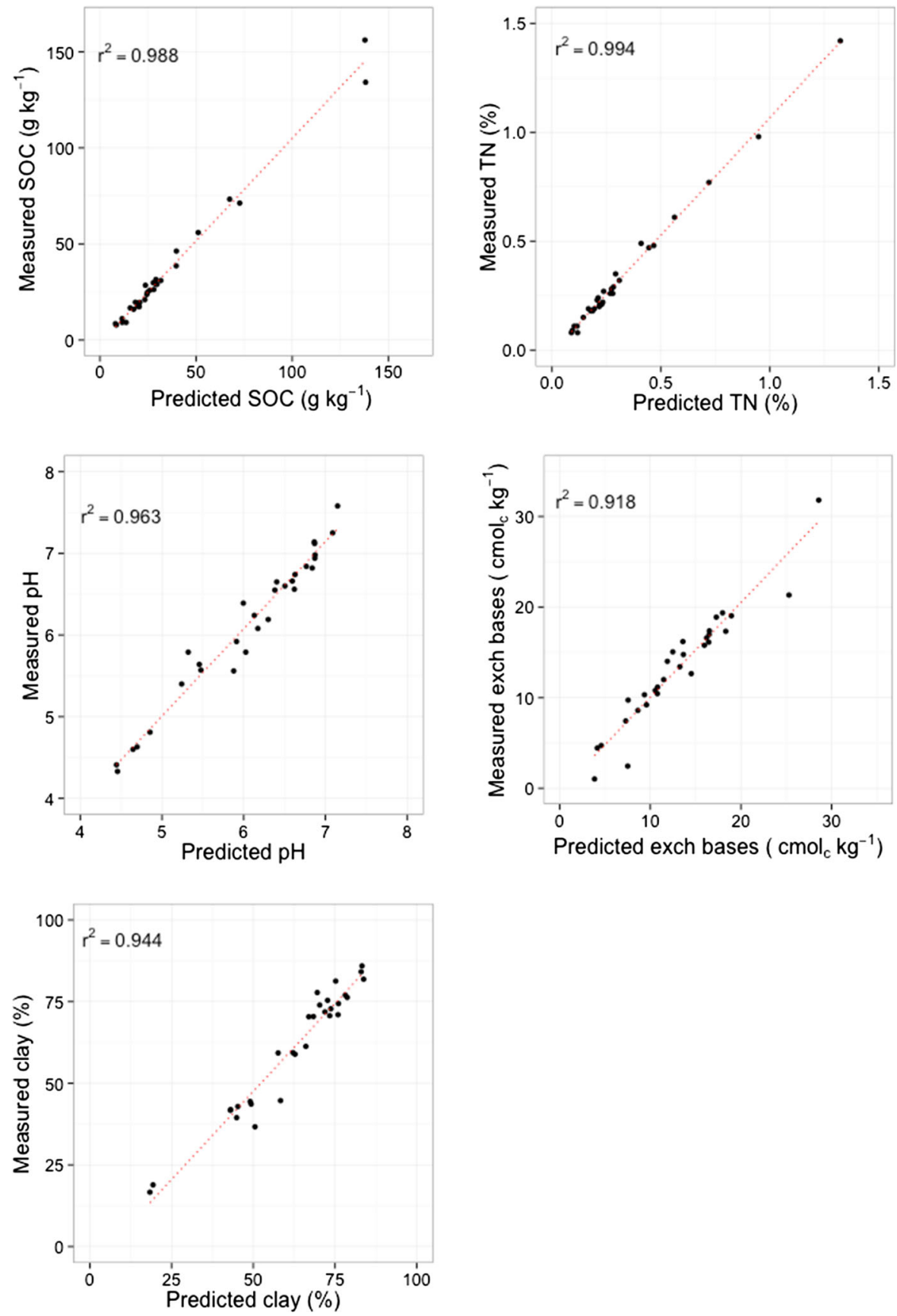

can be used for assessing agricultural productivity. When we applied this threshold to the soils sampled in the study area, $34 \%$ of topsoil in cultivated plots were deficient while less than $0.4 \%$ of topsoil in noncultivated plots were deficient of $\mathrm{N}$.

Cultivation also affects $\mathrm{C}: \mathrm{N}$ of the soil. Our data show that the $\mathrm{C}: \mathrm{N}$ in cultivated plots was lower than in non-cultivated plots, with a mean of $10.7(\mathrm{~min}=7.4$ and $\max =13.9)$ and to $12.0 \quad(\min =7.1$ and $\max =16.4$ ), respectively (Fig. 4). The average C:N for top- and sub-soil samples combined $(\mathrm{n}=320)$ in this study area was 11.1. Depletion of SOC tends to lead to lower $\mathrm{C}: \mathrm{N}$ ratios due, in part to increased rates of soil organic matter oxidation through soil 
Table 1 Soil variables in top and sub soil samples $(\mathrm{n}=320)$

\begin{tabular}{lllll}
\hline Variable & Min & Max & Mean & Standard deviation \\
\hline SOC $\left(\mathrm{g} \mathrm{kg}^{-1}\right)$ & 7.0 & 138.2 & 38.5 & 28.7 \\
$\mathrm{TN}\left(\mathrm{g} \mathrm{kg}^{-1}\right)$ & 0.89 & 13.2 & 3.31 & 2.18 \\
$\mathrm{pH}$ & 4.4 & 7.8 & 5.9 & 0.84 \\
Exchangeable bases $\left(\mathrm{mmol}_{\mathrm{c}} \mathrm{kg}^{-1}\right)$ & 37.1 & 408.9 & 120.4 & 53.6 \\
Clay $(\%)$ & 18 & 90 & 65 & 14 \\
\hline
\end{tabular}

Fig. 3 Boxplots showing the variability of SOC in cultivated top- $(\mathrm{n}=105)$ and sub-soil (105) for and non cultivated top- $(\mathrm{n}=55)$ and sub-soil $(\mathrm{n}=55)$. The dashed vertical line shows mean topsoil organic carbon content in uncultivated plots (71.0 $\mathrm{g} \mathrm{kg}^{-1}$ ), while the dotted vertical line shows mean topsoil organic carbon content in cultivated plots $\left(30.6 \mathrm{~g} \mathrm{~kg}^{-1}\right)$
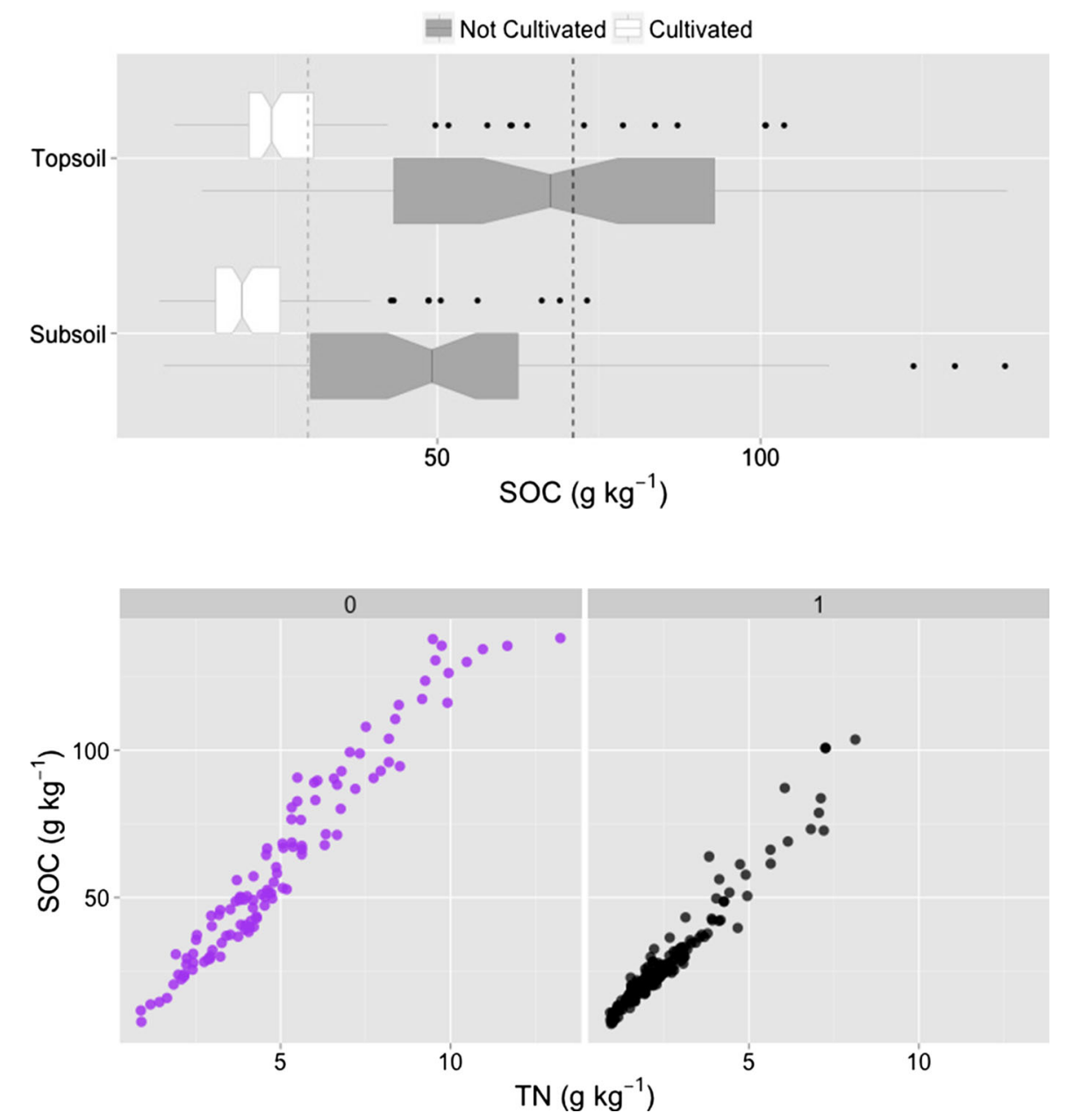

Fig. 4 Relationship between soil organic carbon and total nitrogen in cultivated (1) and non cultivated (0) plots tillage activities, which physically break down the soil organic matter and increases aeration which favor degraders such as aerobic microbes. Land clearing for cultivation also removes perennial vegetation and reduces overall inputs of SOC to the soil. These data indicate the importance of maintaining SOC in the soil in order to improve overall soil fertility.

\section{Effects of trees on SOC}

In the study area, trees have been promoted as part of efforts to restore degraded areas, both through reforestation and agroforestry (Lyamchai et al. 2011). Exotic timber species such as Grevillia robusta and various fruit tree species (including Perse spp. and Prunus spp.) have been widely promoted and are now 
Fig. 5 Tree densities in cultivated (1) and noncultivated (0) plots at different topographic positions in the Lushoto study site. The dotted vertical line shows the average tree density in cultivated plots (89 trees ha $^{-1}$ ), while the dashed vertical line shows the average for noncultivated plots (470 trees $\mathrm{ha}^{-1}$ )

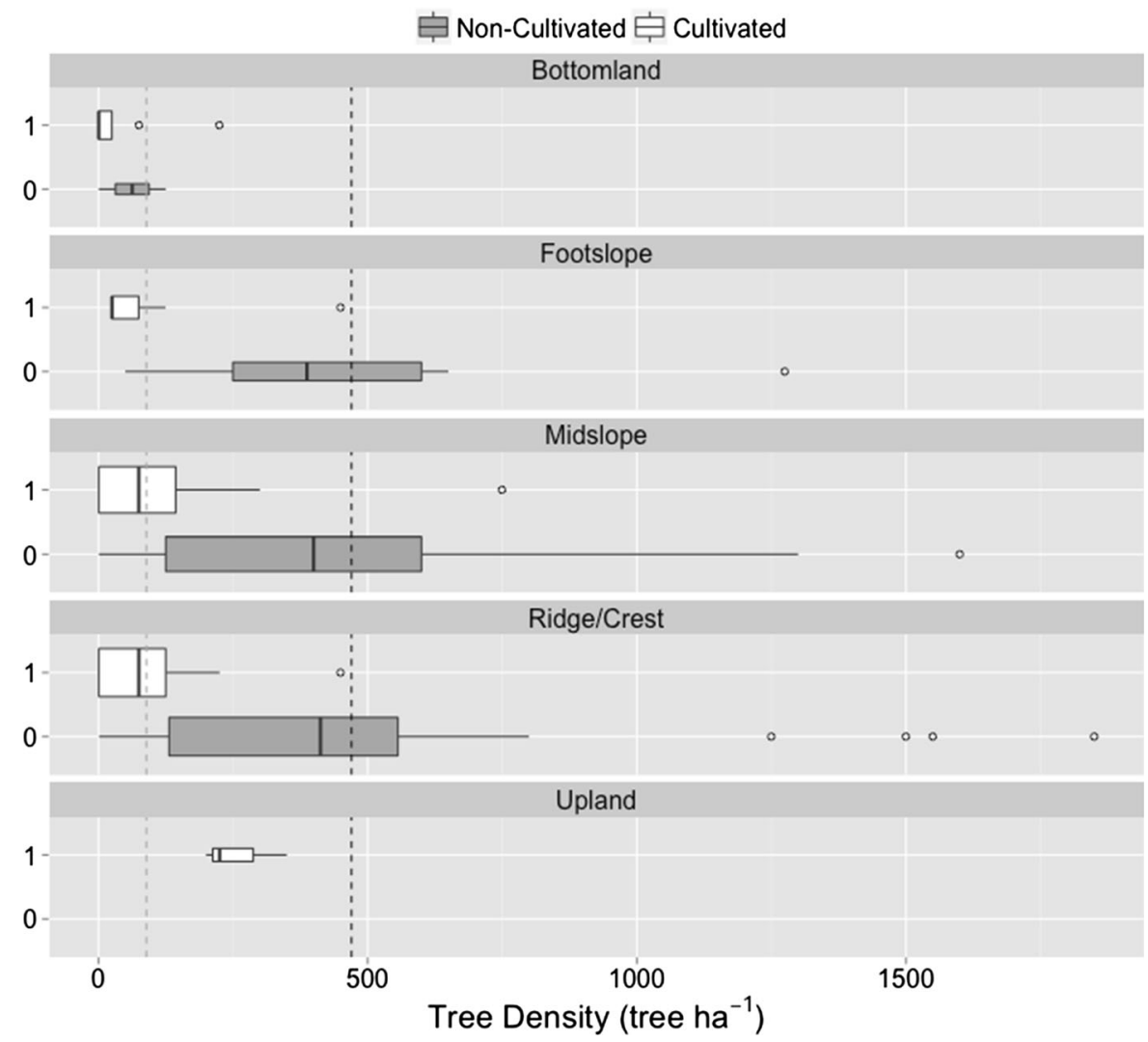

common across the Lushoto district. Our results show that tree densities vary strongly across the Lushoto landscape and are lowest in cultivated fields in bottomlands (Fig. 5). As expected, tree densities were are higher in natural or semi-natural areas compared to cultivated plots (480 and 93 trees ha ${ }^{-1}$, respectively; Fig. 5). Also, there were more trees in cultivated plots on ridges and midslope landscape positions, compared to footslope and bottomlands (Fig. 5).

Overall, $39 \%$ of the sampled plots had G. robusta and $19 \%$ of the plots had fruit trees. Specifically, $29 \%$ of the cultivated plots had fruit trees and approximately $43 \%$ of the cultivated plots had timber species. We therefore assessed the effects of trees on SOC in the study area. In summary, cultivated plots that had trees also had higher topsoil SOC in the $(p<0.005)$, while no statistically significant difference $(p>0.05)$ was found for subsoil SOC. However, the influence of G. robusta on other soil properties still needs further investigation.
Mapping of SOC based on RapidEye satellite imagery

Model performance for the prediction of SOC from RapidEye reflectance for Lushoto was good overall, with an $\mathrm{r}_{\text {calibration of }}^{2} 0.85$ (RMSEP $_{\text {calibration }}=8.0 \mathrm{~g}$

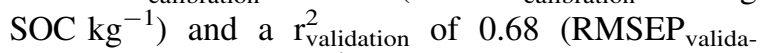
tion $=10.5 \mathrm{~g} \mathrm{SOC} \mathrm{kg}^{-1}$; Fig. 6a). These results are comparable to the prediction model performance reported for Landsat ETM+ from Ethiopia (Vågen et al. 2013a). The resulting map of SOC (Fig. 7) shows the highest predicted values in forested and newly deforested areas in the northern sections of the Lushoto site, and a marked drop in predicted SOC south-west of the site, where the landscape drops onto the plains west of the Usambara mountains. The map also shows a high level of variability within the site and reflects the variability observed in laboratory MIR predicted SOC well, with for example clusters 5, 6 and 11 having the lowest SOC values in the site and also 
Fig. 6 a Topsoil measured SOC vs predicted SOC using RapidEye for Lushoto, for both the calibration (black circles) and validation (red triangles) datasets. b SOC and RapidEye predicted SOC for each sampling cluster. (Color figure online)
Fig. 7 Spatial distribution of predicted topsoil SOC ( $\mathrm{g} \mathrm{kg}^{-1}-0-20 \mathrm{~cm}$ ) based on RapidEye imagery for January 2014 for the Lushoto LDSF site and surrounding areas.

Coordinates on the map are in UTM $37 \mathrm{~S}$
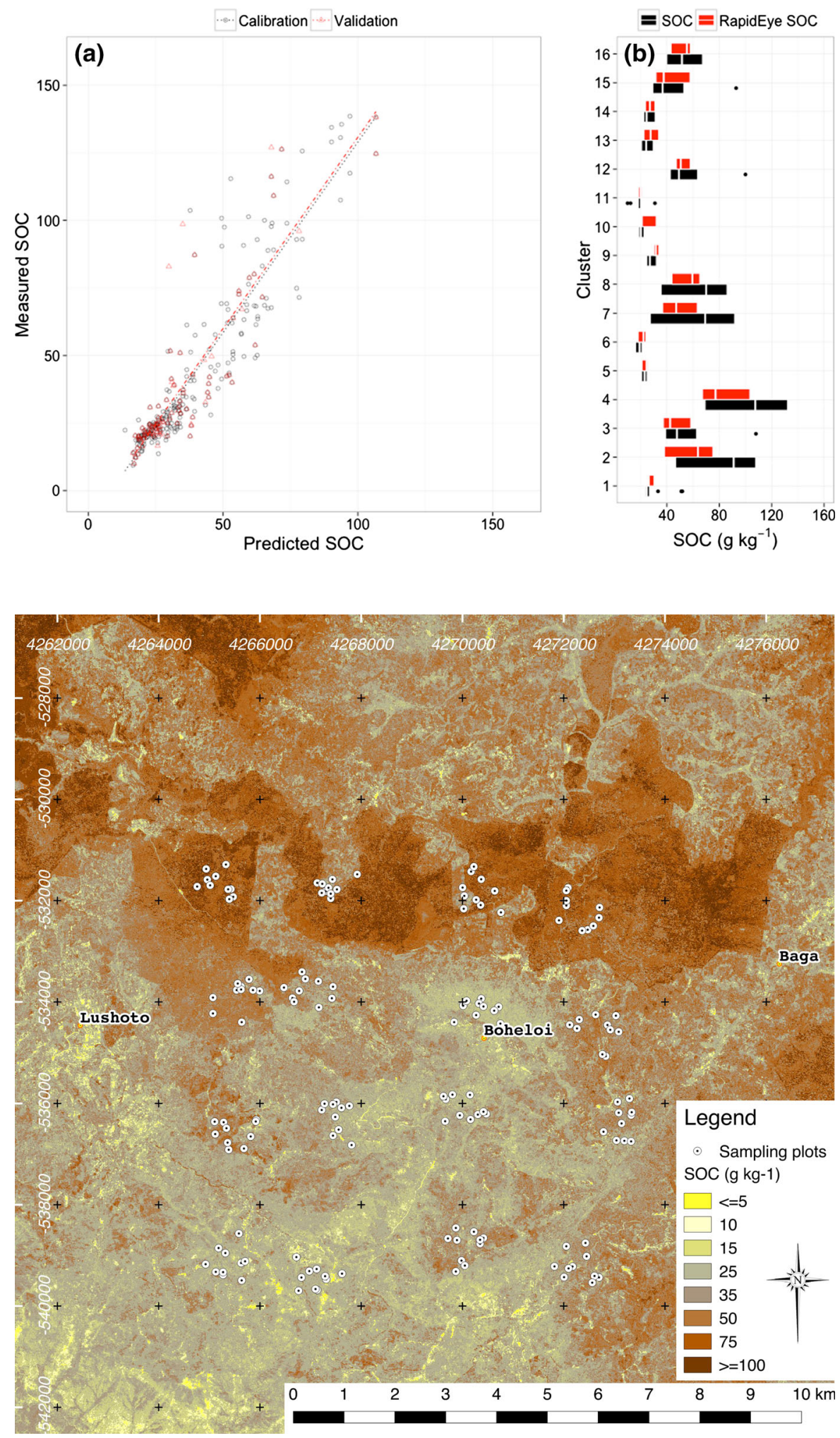
the lowest intra-cluster variability (Fig. 6b). This maps also allows for strategic targeting for management techniques aimed at increasing soil organic matter.

\section{Conclusions}

This study highlights the importance of landscapescale sampling in order to assess the effect of land use on dynamic soil properties, for example SOC. Since the WUM have undergone radical land-use change in the last century, it is important to assess the effects of these changes on soil health, while acknowledging the spatial and temporal variations. These data show that cultivation has a strong effect on reducing SOC across the Lushoto region. This has implications for strategic interventions that improve soil health and agricultural productivity. For example, efforts to incorporate organic matter into the cropping system should be reinforced. Furthermore, due to the high climate variability observed in the region, it appears that implementing climate smart agriculture (CSA) practices may be a reasonable option. This may include implementing simultaneous CSA practices to help build resilience and adaptive capacity of the overall farming system.

This study also highlighted the robustness of using MIR for predicting soil properties and that MIR is an important component of landscape-scale soil sampling efforts. Maps of SOC were generated using RapidEye imagery with good performance. This indicates that fine-scale imagery linked with systematic field surveys can produce high quality maps of soil health indicators. The map of Lushoto illustrated the high SOC variability across the region. This map can also be used for strategic targeting of for land management projects.

Acknowledgments The fieldwork and soil analysis for the samples were funded by the CGIAR Research Program, Climate Change, Agriculture and Food Security (CCAFS). Additional data analysis efforts were made possible with funding from the International Fund for Agricultural Development (IFAD). A special thanks to Scholastica Morrison and the soil processing team in Arusha, Tanzania as well as the entire staff of the ICRAF Soil and Plant Spectroscopy Laboratory in Nairobi, Kenya. Finally, special acknowledgements are extended to Maafaka Ravelona, Phillip Kimeli, Swadakati Juma, Moses Kamau, and all of the farmers in the Lushoto district for contributing to field sampling efforts. Thank you also to the CCAFS East Africa office including James Kinyangi, John Recha, and Maren Radeny for their support. Finally, thank you to Peter Läderach, Anton Eitzinger, Jennifer Twyman, Kelvin Shikuku, Beatriz Rodriguez and Caroline Mwongera for their input.

Open Access This article is distributed under the terms of the Creative Commons Attribution 4.0 International License (http:// creativecommons.org/licenses/by/4.0/), which permits unrestricted use, distribution, and reproduction in any medium, provided you give appropriate credit to the original author(s) and the source, provide a link to the Creative Commons license, and indicate if changes were made.

\section{References}

Berthold MR, Cebron N, Dill F et al (2007) KNIME: the $\{\mathrm{K}\}$ onstanz $\{\mathrm{I}\}$ nformation $\{\mathrm{M}\}$ iner. In: Preisach C, Burkhardt H, Schmidt-Thieme L, Decker R (eds) Data Anal. Mach. Learn. Appl. 31st Annu. Conf. Gesellschaft für Klassif. e.V., Albert-Ludwigs-Universität Freiburgand. Springer, Berlin, pp 319-326

Breiman L (2001) Random forests. Mach Learn 45:35. doi:10. 1023/A:1010933404324

Brown DJ, Shepherd KD, Walsh MG et al (2006) Global soil characterization with VNIR diffuse reflectance spectroscopy. Geoderma 132:273-290. doi:10.1016/j.geoderma. 2005.04.025

Critical Ecosystem Partnership Fund (2005) Eastern arc mountains and coastal forests of Tanzania and Kenya. Briefing book. Cape Town, $162 \mathrm{p}$

Don A, Schumacher J, Freibauer A (2011) Impact of tropical land-use change on soil organic carbon stocks-a metaanalysis. Glob Change Biol 17:1658-1670. doi:10.1111/j. 1365-2486.2010.02336.x

FAO (2013) Climate-smart agriculture sourcebook. United Nations Food and Agriculture Organization, Rome, $570 \mathrm{p}$

Heuvelink GBM, Webster R (2001) Modelling soil variation: past, present and future. Geoderma 100:269-301

Huang B, Sun W, Zhao Y et al (2007) Temporal and spatial variability of soil organic matter and total nitrogen in an agricultural ecosystem as affected by farming practices. Geoderma 139:336-345. doi:10.1016/j.geoderma.2007.02. 012

Kangalawe RYM, Lyimo JG (2013) Climate change, adaptive strategies and rural livelihoods in semiarid Tanzania. Nat Resour 04:266-278. doi:10.4236/nr.2013.43034

Kimaro D, Msanya B, Meliyo J et al (2014) Anthropogenic soils and land use patterns in relation to small mammal and fleaabundance in plague endemic area of Western Usambara Mountains. Tanzan J Health Res, Tanzania. doi:10. 4314/thrb.v16i3.9

Kristjanson P, Neufeldt H, Gassner A et al (2012) Are food insecure smallholder households making changes in their farming practices? Evidence from East Africa. Food Secur 4:381-397. doi:10.1007/s12571-012-0194-Z

Lal R (1987) Managing the soils of Sub-Saharan Africa. Science 236:1069-1076 
Lal R (2007) Carbon management in agricultural soils. Mitig Adapt Strateg Glob Change. doi:10.1007/s11027-0069036-7

Lal R (2010) Enhancing eco-efficiency in agro-ecosystems through soil carbon sequestration. Crop Sci 50:S-120-S131. doi:10.2135/cropsci2010.01.0012

Lal R, Griffin M, Apt J et al (2004) Managing soil carbon. Science 304:393

Lin H, Wheeler D, Bell J, Wilding L (2005) Assessment of soil spatial variability at multiple scales. Ecol Modell 182:271-290. doi:10.1016/j.ecolmodel.2004.04.006

Lundgren L (1980) Comparison of surface runoff and soil loss from runoff plots in forest and small-scale agriculture in the Usambara Mountains. Geogr Ann 62:113-148

Lyamchai C, Yanda P, Sayula G, Kristjanson P (2011) Summary of baseline household survey results: Lushoto. Tanzania, Copenhagen

Madari BE, Reeves JB, Machado PLOA et al (2006) Mid- and near-infrared spectroscopic assessment of soil compositional parameters and structural indices in two Ferralsols. Geoderma 136:245-259. doi:10.1016/j.geoderma.2006.03. 026

Massawe BH (2011) Landform and soil analysis for predicting distribution of plague reservoirs and vectors in Mavumo area, Lushoto District, Tanzania. Thesis, Sokoine University of Agriculture, $156 \mathrm{p}$

Masunga E (2009) Strategic management plan for Shume forest planation (July 2005-June 2010). Interim Report. Lushoto, Tanzania

Mehlich A (1984) Mehlich 3 soil test extractant: a modification of the Mehlich 2 extractant. Commun Soil Sci Plant Anal 15:1409-1416

Msita H (2013) Insights into indigenous soil and water conservation technologies in Western Usambara Mountains, Tanzania. Ph.D. Thesis, Katholieke Universiteit Leuven, $194 \mathrm{p}$

Msita HB, Kimaro DN, Deckers J, Poesen J (2010) Identification and assessment of indigenous soil erosion control measures in the Usambara Mountains, Tanzania. In: Nardali ET (ed) No-till farming: effects on soil, pros cons potential. Agric Issues Policies Ser Nova Science Publishers Inc, New York, pp 49-79

Ndakidemi PA, Semoka JM (2006) Soil fertility survey in western Usambara Mountains, northern Tanzania. Pedosphere 16:237-244

Ogle SM, Breidt FJ, Paustian K, Breidt J (2005) Agricultural management impacts on soil organic carbon storage under moist and dry climatic conditions of temperate and tropical regions. Biogeochemistry 72:87-121. doi:10.1007/s10533004-0360-2

Post W, Mann L (1990) Changes in soil organic carbon and nitrogen as a result of cultivation. Soils Greenh, Eff

R Core Team (2015) R: a language and environment for statistical computing. R Foundation for Statistical Computing, Vienna. http://www.R-project.org/

Reeves J III, Follett R, McCarty G, Kimble J (2006) Can near or mid-infrared diffuse reflectance spectroscopy be used to determine soil carbon pools? Commun Soil Sci Plant Anal 37:2307-2325. doi:10.1080/00103620600819461
Robertson GP, Crum JR, Ellis BG (1993) Spatial variability of soil resources following long-term disturbance. Oecologia $6: 451-456$

Rwehumbiza FBR (2014) A comprehensive scoping and assessment study of Climate Smart Agriculture (CSA) policies in Tanzania. Morogoro, $29 \mathrm{p}$

Schlesinger WH (1997) Biogeochemistry: an analysis of global change, 2nd edn. Academic Press, San Diego

Shepherd K, Walsh M (2002) Development of reflectance spectral libraries for characterization of soil properties. Soil Sci Soc Am J 66:988-998

Swift MJ, Shepherd KD (2007) Saving Africa's soils: science and technology for improved soil management in Africa. Nairobi, Kenya

Tenge AJ, De graaff J, Hella JP (2005) Financial efficiency of major soil and water conservation measures in West Usambara highlands, Tanzania. Appl Geogr 25:348-366. doi:10.1016/j.apgeog.2005.08.003

Tenge AJ, Okoba BO, Sterk G (2007) Participatory soil and water conservation planning using a financial analysis tool in the West Usambara Highlands of Tanzania. Land Degrad Dev 337:321-337. doi:10.1002/ldr

Terhoeven-urselmans T, Vagen T, Spaargaren O, Shepherd KD (2010) Prediction of soil fertility properties from a globally distributed soil mid-infrared spectral library. Soil Sci Soc Am J. doi:10.2136/sssaj2009.0218

Tittonell P, Giller KE (2013) When yield gaps are poverty traps: the paradigm of ecological intensification in African smallholder agriculture. Field Crops Res 143:76-90. doi:10.1016/j.fcr.2012.10.007

URT (2001) Agricultural sector development strategy. Dar es Salaam, $73 \mathrm{p}$

URT (2008) Agriculture sector review and public expenditure review 2008/09. Dar es Salaam, 110 p

URT (2011) Tanzania Agricultural and Food Security Investment Plan (TAFSIP) 2011-12 to 2020-21: main document. Dar es Salaam, $75 \mathrm{p}$

URT (2012) Guidelines for integrating climate change adaptation into national sectoral policies, plans and programmes of Tanzania. Dar es Salaam, $60 \mathrm{p}$

Vågen T-G, Gumbritch T (2012) Sahel atlas of changing landscapes: tracing trends an variations in vegetation cover and soil condition, 1st edn. UNEP, Nairobi

Vågen T-G, Lal R, Singh BR (2005) Soil carbon sequestration in sub-Saharan Africa: a review. Land Degrad Dev 71:53-71. doi:10.1002/ldr.644

Vågen T-G, Shepherd KD, Walsh MG, Va T (2006) Sensing landscape level change in soil fertility following deforestation and conversion in the highlands of Madagascar using Vis-NIR spectroscopy. Geoderma 133:281-294. doi:10.1016/j.geoderma.2005.07.014

Vågen T-G, Shepherd KD, Walsh MG et al (2010) AfSIS Technical Specifications Soil Health Surveillance. CIAT (the AfSIS project), Nairobi, Kenya

Vågen T-G, Davey FA, Shepherd KD (2012) Land health surveillance: mapping soil carbon in Kenyan Rangelands. In: Nair PKR, Garrity D (eds) The future of global land use (advances in agroforestry). Springer, New York, pp 455-462 
Vågen T-G, Winowiecki LA, Abegaz A, Hadgu KM (2013a) Landsat-based approaches for mapping of land degradation prevalence and soil functional properties in Ethiopia. Remote Sens Environ 134:266-275

Vågen T-G, Winowiecki LA, Tamene Desta L, Tondoh JE (2013b) The Land Degradation Surveillance Framework (LDSF)—field guide v3. World Agroforestry Centre, Nairobi

Vågen T-G, Winowiecki LA, Tondoh JE et al (2016) Mapping of soil properties and land degradation risk in Africa using MODIS reflectance. Geoderna 263:216-225

Van Olmen I (2008) Influence of landscape factors and human connectivities on the incidence of human plague occurrences in Lushoto. Katholieke Universiteit, Northeastern Tanzania
Vanlauwe B, Descheemaeker K, Giller KE et al (2014) Integrated soil fertility management in sub-Saharan Africa: unravelling local adaptation. Soil Discuss 1:1239-1286. doi:10.5194/soild-1-1239-2014

Victoria R, Banwart S, Black H et al (2012) Benefits of soil carbon. UNEP yearbook. United Nations Environmental Programme, New York, 33 p

Wand M (2015) KernSmooth: functions for kernel smoothing supporting Wand \& Jones (1995). R package version 2.2314

Wickama J, Okoba B, Sterk G (2014) Effectiveness of sustainable land management measures in West Usambara highlands, Tanzania. Catena 118:91-102 